Y, $\triangle \mathrm{K} 342.2$

ББК 67.400 .5

DOI 10.22394/1682-2358-2019-6-80-86

S.R. Gadisov, lecturer of the Civil Law and Proceedings Department, Povolzhsky Institute of Management named after P.A. Stolypin, Branch of the Russian Presidential Academy of National Economy and Public Administration

\section{STATE SOVEREIGNTY IN THE CONTEXT OF GLOBALIZATION: FACTOR ANALYSIS}

Technological, economic, socio-cultural and other conditions for the formation of transnational relations and their impact on sovereign states functioning are analyzed. The author proposes to consider the interaction of sovereignty and globalization as forms of state activity. Attention is paid to delegation of sovereign rights by the state to an authorized organization at the supranational level.

Key words and word-combinations: globalization, sovereignty, functions of the state, supranational organizations, sovereign rights.
C.P. Гадисов, преподаватель кафедрь гражданского права и прочесса Поволжского института управления имени П.А. Стольпина филиала Российкой академии народного хозяйсmъа и государственной службь при Президенте РФ (email: seymur01@bk.ru)

\section{СУВЕРЕНИТЕТ ГОСУААРСТВА В УСАОВИЯХ ГАОБААИЗАЦИИ: ФАКТОРНЫЙ АНААИЗ}

Аннотация. Анализируются технологические, экономические, социокультурные и другие условия становления транснациональных связей и их влияние на функционирование суверенных государств. Предлагается рассматривать взаимодействие суверенитета и глобализации через призму форм государственной деятельности. Обращается внимание на делегирование государством своих суверенных прав уполномоченной организации наднационального уровня.

Ключевые слова и словосочетания: глобализация, суверенитет, функции государства, наднациональные организации, суверенные права.

$\Pi$ онимание структуры и функциональных особенностей геополитической среды, в которой существует и развивается государственный суверенитет, в полной мере определяется научными представ ениями о глобамизации и природе транснациональных процессов, формирующих ее содержкание. Проблема, однако, в том, что определения глобамизации большей частью 
имеют предельно обобщенное содержание и отличаются высокой степенью разнородности. Анализ научной митературы позволяет выделить несколько авторов, точка зрения которых выражает мнение той или иной группы исследователей глобализации.

В частности, культуролог М. Маклюэн опредемяет данное понятие как «гмобальный диамог» [1, с. 13]. По мнению социолога Э. ГидАенса, глобализация - это «интенсификация всемирных социальных отношений» [2, с. 32]. Иное социологическое опредемение дает У. Бек. Гцобализация, с его точки зрения, представцяет собой проџесс создания транснаџиональных связей и единого соџиокультурного пространства, сопровождаемый обесцениванием мокамьных культур и их замещением третьими культурами [3, c. 22].

С позиции теории права глобализация опредемяется А.П. Рассказовым как «неравномерный процесс становления и функционирования системной взаимосвязанности стран, народов во всех сферах жизнедеятельности общества (экономика, политика, право, культура, соџиальная сфера, идеология и т.А.), который приводит к осознанию мира как единого цемого, гАе все страны и народы подчинены закону взаимного соприкосновения, взаимообмена и взаимодействия со всеми его плюсами и минусами» [4, с. 450].

Обобщенность изможенных определений и нечеткость их понятийных элементов, как это следует из приведенных высказываний, создают значительные препятствия при попытке научного анализа сущности суверенитета и глобализаџии на основе конвергенџии данных теоретических конструкџий.

В связи с этим следует согласиться с А.А. Сафоновым, предложившим конџептуально новый подхоА к исследованию сущности глобализаџии. Методологической основой теории глобализаџии является общефимософская доктрина, согласно которой понимание всякой сущности основано на Авух компонентах - Аескриптивном и нормативном. Аескриптивный компонент теории представмяет собой деятельность субъекта познания по осмыслению сущностей объективного мира, Аанных ему в ощущениях. По сути, Аескриптивный компонент преАставмяет собой описание сущностей, вкцючая соџиальные в том виде, в котором субъект наблюдает их в настоящий момент.

Нормативный компонент выступает в виде представлений о Аолжном, то есть о том, какой исследуемая сущность домжна быть с точки зрения пре Аставлений и системы этических џенностей познающего субъекта. Иными словами, нормативный компонент общефилософского подхода преАставляет собой идеальную модель сущности, отраженную в сознании познающего субъекта. Именно нормативный компонент общефилософского подхода в наибольшей степени подвержен политическим, соџиально-экономическим и культурно-идеологическим факторам индивидуального и общественного сознания. По замечанию А. $\Lambda$. Сафонова, наиболее ярко различия нормативного компонента общефицософского подхода проявАяются в субъективном, инструментальном, идеологическом содержании теорий глобализаџии, обусмовменным «соџиальной, цивилизационной и корпоративной принадлежнос- 
тью исследователя, и, шире, определенной научной школы или научного сообщества» [5, с. 11] .

Приведенные доводы объясняют, почему глобалистика как система научных преАставлений об общемировых соџиально-экономических и культурноидеологических процессах, с одной стороны, опирается на общепризнанные представления, а с Аругой, содержит Аифференцированные положения, отражающие, главным образом, противоборство интересов и ценностей соџиальных групп. В свою очередь, общепризнанные элементы явцяются твердой методологической основой научного анализа сущности глобализации, позвоцяющей в рамках преАставленной темы получать достоверные, свободные от идеологических и иных догм выводы о развитии государственно-правового содержания суверенитета в условиях глобализаџии.

К общепризнанным элементам разнообразных теоретических моделей относят прежке всего определение глобализации как формы взаимодействия государств и цивилизаций, признание объективного характера проџессов, составцяющих ее содержание, а также их соџиацьно-исторический детерминизм [6]. Исследование соџиально-исторической обусловленности и хрономогических координат возникновения глобализаџии имеет особое значение в рамках рассматриваемой темы, так как позволяет опредецить соџиально-помитические условия глобализаџии и связанные с ними особенности правового регулирования деятельности государства на внутриполитическом и наднациональном уровнях осуществления суверенитета.

Р. Иеринг, рассматривая вопросы взаимодействия общества и государства, отмечал, что важной стороной такого взаимодействия явцяется общение межАу народами, усвоение и ассимицяџия. В этом он видел и основную цель соџиального развития: «Жизнь народов Аолжна состоять в формировании системы взаимных соприкосновений и вцияний разного качества, свойства, характера» $[7$, c. 67$]$.

Опираясь на выводы Р. Иеринга, отдельные исследователи стали связывать исторические предпосыцки глобализации с торговыми отношениями эмиинистического периода, Вестфальским договором 1648 г., который сыграц решающую роль в установлении суверенитета государств Европы, и с развитием процессов колониального порабощения народов мира империалистическими государствами-метрополиями в XIX - первой половине XX в. [8, с. 116] .

Указанная периодизация вызвала вполне справедиивую критику ряда авторов, общее мнение которых выразил В.А. Иноземцев, отметив, что основным недостатком такого подхода является подмена понятий. «Процессы, называемые глобализацией, - отмечал В.А. Иноземцев, - на поверку оказывались естественным результатом освоения сначала европейцами, а затем и представителями western offshoots все новых регионов пианеты» [9, c. $164-165]$.

На наш взгляА, следует согласиться с исследователями, которые относят начальную точку хронологического периода формирования глобализма к середине ХХ в. и связывают ее с результатами Второй мировой войны, а также крушением мировой колониальной системы и появлением значительного ко-

82 Bulletin of the Volga Region Institute of Administration • 2019. Vol. 19. № 6 
мичества суверенных государств в результате победы национально-освободительного движения в странах Азии, Африки и Аатинской Америки.

Именно к этому моменту относится возникновение фундаментальной основы механизма функционирования глобализации, который оформился в виде четкого разделения политической структуры мира на два типа государств эксплуатирующего центра и эксплуатируемой периферии [10, с. 45]. Рассматривая сущность и функщии глобализации, исследователи выдемяют ряА социополитический условий, сформировавшихся по окончании Второй мировой войны, наличие которых позволицо запустить действие механизма осушествления транснациональных процессов.

Ю.В. Яковещ выдемяет пять групп таких условий - идеологические, геополитические, экономические, соџиокультурные и технологические [11, с. 132-164]. КажАая из этих групп представмяет собой совокупность объективных социально-экономических предпосылок и государственно-правовых, идеологических, этических и других среАств воплощения в действительность глобальных процессов в экономике, политике, культуре, идеологии и иных сферах соџиального бытия.

Обозначенные условия глобализации и их непосредственное влияние на осуществление национальными государствами своих функций стали основой Аля высказывания мнений о деформировании государственного суверенитета под влиянием транснациональных процессов в экономике, политике, идеологии и Аругих сферах соџиального бытия [12, с. 15]

В основе геополитических условий межит противостояние основных мировых соџиальных моделей - имеющей экономическое превосходство западной модели и обладающей многократным превосходством по количеству населения восточной модели [13, p. 18].

Геополитические условия глобализаџии и противостояние западной и восточной модемей соџиального развития детерминировали появление наднациональных организаций, которым государства-члены делегировали свои суверенные полномочия. В качестве примера современных наднаџиональных организаций можно привести организации экономического сотрудничества ЕврАзЭС, БРИКС, ЕЭС; организаџии в сфере обороны - НАТО, ШОС и т.п. $[14$, c. 8$]$.

Экономические условия глобализаџии, связаны прежде всего с процессами формирования транснациональной экономики как самостоятельной системы. Как отмечац Э.Н. Тужба, фундаментом транснациональной экономики явмяется глобальное раздемение труда, а формой - взаимозависимость экономик разных стран и регионов мира $[15$, с. 15$]$. Особую роль в становлении и развитии правового регулирования процессов транснациональной экономики сыграло законодательство о так называемых еврорегионах. По определению спеџиалиста в сфере экономической географии, В.А. Аергачева, еврорегионы - это приграничные сообщества международного трансграничного сотрудничества европейских стран в обцасти экономики, культуры, образования, транспорта, экологии и Аругих, создаваемые на основе принципов субсидиарности [16]. Примером подобных законодатель- 
ных актов явцяется договор о статусе еврорегиона «Рейн-Вааль», образованного в 1993 г. Указанный нормативный документ представмяет собой соглашение о территориальном сотрудничестве, подписанное межАу Авумя федерацьными землями Германии (Северный Рейн-Вестфалия и Нижняя Саксония) и Королевством Нидерланды [17]. Именно правовое регулирование статуса экономических зон еврорегионов стало основой Аця формирования межгосударственных соглашений глобального экономического сотрудничества.

К соџиокультурным относятся условия, позволяющие стандартизировать этические, идеологические, ценностные, политико-правовые и Аругие структуры регионацьного общественного сознания на основе интегративных сощиокуиьтурных представлений развитых государств, выступающих инициаторами проџессов глобализаџии. Основным проводником глобалистических представлений явцяются средства массовой информации и разнообразные преАставители западной культуры. ОАнако и праву принадмежкит Аалеко не последняя роль в стандартизаџии и унификаџии политико-правовой сферы.

Примером могут выступать прелиминарные закцючения, то есть такие определения СУАа ЕС, которые выносятся по поводу юридической состоятельности того или иного общеевропейского акта или же соответствия актов, исходящих от наџионацьных институтов государств - чиенов Европейского союза, общеевропейскому законодательству [18]. Аругим примером явмяются общие принщипы права ЕС, под которыми понимаются основные права и свободы в том виде, как они закреплены в Европейской Конвенџии о защите прав человека и основных свобод, подписанной в Риме 4 ноября 1950 г., и как они вытекают из общих демократических конституџионных традиџий государств-чиенов [19, р. 91] .

Начало формирования технологической группы условий относится к сереАине 1950-х годов, когда в процессе научно-технической революции запаАные страны освоили применение результатов исследований фундаментальных наук. Развитие техносферы, ознаменовавшее переход к постиндустриальной экономике и общемировому технологическому пространству, привело к появцению неизвестных в предыдущие эпохи соџиально-экономических и политических противоречий мирового сообщества. Образовался и стал стремительно расширяться научно-технологический разрыв между государствами-лидерами и отстающими странами и цивикизациями.

В цемях придания этому процессу «мавинообразного характера», государства-лидеры, такие как США, ФРГ, Великобритания, иниџиировали принятие целого ряда научных и образовательных программ, обеспечивающих миграцию в развитые страны носителей интемлектуального богатства. Это европейские программы поддержки мобильности и академического сотрудничества: Аеонардо (профессиональная подготовка), Комениус (школьные обмены и языковая подготовка), Грунтвиг (повышение квацификации и переподготовка), Аингва (обмен студентами и преподаватемями, изучающими и преподающими иностранные языки) [20] . 
В аспекте рассматриваемой темы цемесообразно изучение не только социополитических условий механизма осуществления глобализации, но и прежде всего государственно-правовых механизмов осуществления глобальных транснациональных процессов и выявление воздействия, которое они оказывают на современное государство. Эти механизмы проявмяются в первую очередь посредством функций современного государства.

Итак, сквозь призму противостояния двух мировых соџиальных модемей западной и восточной, можно наглядно проанализировать эволюџию научных представлений о государственных функщиях. Общепринятой считается точка зрения, высказанная Н.В. Черноголовкиным о том, что функџии государства представмяют собой направления его деятельности или возможности Аля реамизаџии государственного суверенитета $[14$, с. 6] . В связи с этим ученый кмассифиџировал функции государства на внутренние (экономическая функция, а также социальная и т.п.) и внешние (функция обороны, международного сотрудничества и т.п.).

Очевидно, что если ранее четко прослеживалось разделение государственных функџий на внешние и внутренние, то в современных условиях разделение и тех, и Аругих на исключительно внешние и исключительно внутренние довольно затруднительно. К примеру, Ааже такая сугубо внутренняя функция, как охрана общественного порядка, в условиях глобализации приобретает и внешнее содержание, например, сотрудничество по минии Интерпома [21, с. 263]. В таком аспекте не представмяется также целесообразным классифиџировать функщии государства на генеральные и единичные, как это предлагает ряА исследователей [22, с. 219].

Полагаем, что с учетом изменений соџиально-экономической структуры мирового общественного уклада, явившихся следствием объективных процессов глобализации, представляется цемесообразным отказаться от общей кмассификации государственных функций на внешние и внутренние, так как в настоящее время все без исключения функции государства, с одной стороны, могут быть распространены на уровень наднаџиональных отношений и осуществляться за пределами суверенитета национального государства, а с Аругой, мюбая функция, ограниченная внутренним пространством государственного суверенитета, в настоящее время не может сушествовать и развиваться изолированно от функщий наднациональных агломераций, в состав которых входит данное государство.

ОАнако суверенитет явмяется неотъемлемым качеством государства как социально-политического образования, единым и единственным признаком, указывающим на самостоятельность и независимость государства в решении всех вопросов, касающихся реализаџии государственных функций. По мнению В.Е. Чиркина, публичная власть наднаџиональных политических образований, вкмючая Европейский союз, не является суверенной [23, с. 136-137]. ВАасть наднациональных организаций представляет собой совокупность суверенных прав, делегированных им государствами - чкенами этих организаџий. Основное отличие наднациональной власти от суверенной заключается в том, что в Аюбой момент Аелегированные полномочии могут быть отозваны Аюбым государством-чменом. 
В связи с изложенным полагаем, что уместно говорить не о взаимодействии суверенитета и глобализации, а об изменении форм государственной Аеятельности по осуществлению государством своих функщий. ОАним из направлений этой деятельности явцяется делегирование суверенных прав уполномоченной организации на наднациональном уровне, в результате чего происходит трансформация характера, возможностей и пределов государственной власти, а также видов и полномочий государственных органов, способов реализации и юридического оформления государственной вцасти в центре и на местах, явившиеся следствием интеграционных факторов технологического, экономического, геополитического и соџиокуиьтурного мирового общественного укцада.

\section{Библиографический список}

1. Маклюэн М. Галактика Гутенберга: Становление человека печатающего / пер. с англ. И.О. Тюриной. 3-е изд. М., 2015.

2. Гидденс Э. Устроение общества: Очерк теории структурации // Гидденс Э. Собр. соч. 2-е изд. М., 2005.

3. Бек У. Что такое глобализация? / пер. с нем. А. Григорьева, В. Седельника. М., 2001.

4. Рассказов Л.П. Теория государства и права. М., 2016.

5. Сафонов А.Л. Глобализация: структура, сущность, атрибуты. М., 2014.

6. Фукуяма Ф. Конец истории и последний человек. М., 2005.

7. Иеринг Р. Цель в праве: в 2 т. СПб., 1881. Т. 1.

8. Горелов А.А., Горелова Т.А. Глобализация и глобальный неоколониализм // PolitBook. 2013. № 3 .

9. Иноземцев В.Л. Глобализация и неравенство: что - причина, что - следствие? // Россия в глобальной политике. 2003. № 1, т. I.

10. Яницкий О.Н. Перспективы глобализации (по страницам нового журнала «Россия в глобальной политике») // Социологическое обозрение. 2003. № 2, т. 3.

11. Яковец Ю.В. Глобализация и взаимодействие цивилизаций. М., 2003.

12. Shau J. Law of the European Union. London: Palgrave Macmillan, 2000.

13. Basa K.K. Globalization and Cultural Heritage in the Third World // Journal of the Indian Anthropological Society. 2004. № 39.

14. Черноголовкин Н.В. Теория функций социалистического государства. М., 1970.

15. Тужба Э.Н. Глобализация - основные измерения и подходы к пониманию // Общество: социология, психология, педагогика. 2011. № 1-2.

16. Сайт профессора В.А. Дергачева. URL: http://www.dergachev.ru/ (

17. Euregio Rhein-Waal 1993. URL: http://www.euregio.org

18. Никодимов И.Ю. Основные критерии систематизации функций современного государства // Гуманитарные, социально-экономические и общественные науки. 2014. № 9.

19. Протокол о Статуте Суда Европейского союза. URL: http://eulaw.ru/treaties/protoc/3\#1.

20. Черноголовкин Н.В. Теория функций социалистического государства. М., 1970.

21. Ананьев А.А., Потапенко А.В., Селищева Т.А., Чжао Вэй Ди. Европейская экономика и идея многополярного мира в контексте глобализации и регионализации // Проблемы современной экономики. 2016. № 1.

22. Тихонов А.А. Правовые основы и приоритетные направления совершенствования международного сотрудничества полицейских // Вестник Московского университета МВД России. 2012. № 1 .

23. Чиркин B.E. Наднациональное право: основные особенности // Журнал российского права. 2017. № 2. 